\title{
Detection of Neisseria gonorrhoeae bacterial loads in the pharynx and saliva among men who have sex with men
}

\author{
Eric P.F. Chow ${ }^{1,2}$, Sepehr N Tabrizi ${ }^{3-5}$, Samuel Phillips ${ }^{3,5}$, David Lee ${ }^{1}$, Catriona S Bradshaw ${ }^{1,2}$, \\ Marcus Y Chen ${ }^{1,2}$, Christopher K Fairley ${ }^{1,2}$
}

\author{
1. Melbourne Sexual Health Centre, Alfred Health, Melbourne, VIC, Australia \\ 2. Central Clinical School, Monash University, Melbourne, VIC, Australia \\ 3. Department of Microbiology and Infectious Diseases, The Royal Women's Hospital, Parkville, VIC, Australia \\ 4. Department of Obstetrics and Gynaecology, University of Melbourne, Parkville, VIC, Australia \\ 5. Murdoch Childrens Research Institute, Parkville, VIC, Australia
}

\section{Introduction}

$>$ Kissing, oro-anal (rimming), oral-penile sex, and saliva use as a lubricant for anal sex are all associated with detection of gonorrhoea.

- Studies have shown gonorrhoea can be cultured from saliva samples but none of these studies examined the gonococcal bacterial DNA load in saliva.

$>$ If saliva can be acted as a medium for gonorrhoea transmission, it is important to understand the relative concentrations of bacteria at different anatomical sites to provide further understanding on gonorrhoea transmission.

\begin{tabular}{|l|}
\multicolumn{1}{c|}{ Aim } \\
\hline$>$ \\
$\begin{array}{l}\text { To quantify the gonococcal bacterial DNA load in saliva and } \\
\text { pharynx. }\end{array}$ \\
\hline
\end{tabular}

\section{Methods}

$>$ Pharyngeal and saliva specimens were collected on the day men who have sex with men (MSM) returned for treatment of pharyngeal gonorrhoea at the Melbourne Sexual Health Centre, Australia, between October 2014 and March 2015.

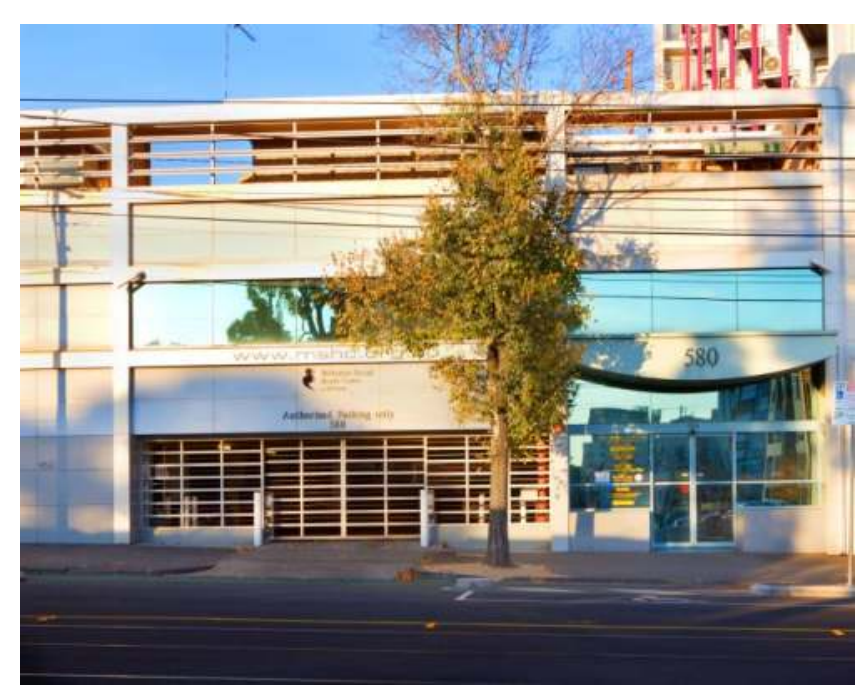

Participants were then instructed to masticate and allow the saliva to accumulate in the mouth for 60 seconds and then expectorated into a sterile plastic specimen jar and then a cotton-tipped swab was swirled in the saliva. The swab with saliva specimen was plated immediately onto GC Agar medium for culture.

$>$ Pharyngeal specimens were taken from the tonsillar fossae and the posterior oropharynx using cotton-tipped swabs by three experienced sexual health clinicians, and the swabs were plated immediately onto GC Agar medium for culture separately.

$>$ An additional pharyngeal swab was taken for nucleic acid amplification test (NAAT) and then placed in $0.4 \mathrm{ml}$ of phosphate buffered saline (PBS).

$>$ An aliquot of $5 \mu 1$ of extracted DNA was amplified. $\beta$-globin control was used to assess the specimen adequacy. $N$. gonorrhoeae porA and opa qPCR assays were used to ensure relative bacterial DNA load was not extremely different, and the opa gene was used to express the quantitation of DNA load.

\section{Contact Details}

Dr Eric PF Chow, PhD

Melbourne Sexual Health Centre

580 Swanston Street, Carlton, VIC 3053, Australia

Phone: +61 (3) 9341-6233

Email: Echow@mshc.org.au

\section{Results}

$>$ A total of 33 MSM at MSHC had a positive culture for pharyngeal gonorrhoea at screening and returned to our centre for antibiotic treatment within 14 days during the study period were included.

$>\beta$-globin was detected in all pharyngeal and saliva specimens from the 33 participants (median: $4.5 \times 10^{5}$ copies/swab; IQR: $1.4 \times 10^{5}-$ $\left.8.7 \times 10^{5}\right)$.

$>$ The median bacterial DNA load did not differ between 14 men with a culture-positive pharyngeal specimen $\left(2.5 \times 10^{5} \mathrm{copies} / \mathrm{swab}\right.$; log 5.4) and 19 men with a culture-negative pharyngeal specimen (2.9 $\times 10^{4}$ copies/swab; $\left.\log 4.5\right)$ (Mann-Whitney, $\mathrm{p}=0.166$ ).

$>$ The median bacterial DNA load in saliva was similar between 6 men with a culture-positive saliva specimen $\left(2.2 \times 10^{5} \mathrm{copies} / \mathrm{ml}\right.$; log 5.3) and 26 men with a saliva-negative saliva specimen $\left(2.7 \times 10^{5}\right.$ copies/ml; $\log 5.4$ ) (Mann-Whitney, $\mathrm{p}=0.499$ ).

Table 1. Gonococcal bacterial DNA loads in the pharynx by culture and NAAT.

\begin{tabular}{|c|c|c|c|c|c|c|}
\hline & \multicolumn{4}{|c|}{ Positive NAAT } & \multicolumn{2}{|c|}{ Negative NAAT } \\
\hline & n & $\begin{array}{c}\text { Median } \\
\text { NG loads } \\
\text { [IQR] }\end{array}$ & $\begin{array}{c}\log _{10} \\
\text { median } \\
\text { NG } \\
\text { loads } \\
\text { [IQR] }\end{array}$ & $\mathrm{n}$ & $\begin{array}{c}\text { Median } \\
\text { NG loads } \\
\text { [IQR] }\end{array}$ & $\begin{array}{c}\log _{10} \\
\text { median } \\
\text { NG } \\
\text { loads } \\
\text { [IQR] }\end{array}$ \\
\hline $\begin{array}{l}\text { Culture } \\
\text { positive }\end{array}$ & 14 & $\begin{array}{l}248,512 \\
{[56,219-} \\
2,943,254]\end{array}$ & $\begin{array}{l}5.4 \\
{[2.8-6.5]}\end{array}$ & 19 & $\begin{array}{l}29,285 \\
{[790-} \\
462061]\end{array}$ & $\begin{array}{l}4.5 \\
{[2.9-5.7]}\end{array}$ \\
\hline $\begin{array}{l}\text { Culture } \\
\text { negative }\end{array}$ & 31 & $\begin{array}{l}170,493 \\
{[2,824-} \\
2,571,742]\end{array}$ & $\begin{array}{l}5.2 \\
{[3.5-6.4]}\end{array}$ & - & - & - \\
\hline
\end{tabular}

Table 2. Gonococcal bacterial DNA loads in saliva by culture and NAAT.

\begin{tabular}{|c|c|c|c|c|c|c|}
\hline & \multicolumn{4}{|c|}{ Positive NAAT } & \multicolumn{2}{|c|}{ Negative NAAT } \\
\hline & $\mathrm{n}$ & $\begin{array}{l}\text { Median } \\
\text { NG loads } \\
\text { [IQR] }\end{array}$ & $\begin{array}{c}\log _{10} \\
\text { median } \\
\text { NG } \\
\text { loads } \\
\text { [IQR] }\end{array}$ & $\mathrm{n}$ & $\begin{array}{c}\text { Median } \\
\text { NG loads } \\
\text { [IQR] }\end{array}$ & $\begin{array}{c}\log _{10} \\
\text { median } \\
\text { NG } \\
\text { loads } \\
\text { [IQR] }\end{array}$ \\
\hline $\begin{array}{l}\text { Culture } \\
\text { positive }\end{array}$ & 6 & $\begin{array}{l}219,821 \\
{[65,919-} \\
1,112,657]\end{array}$ & $\begin{array}{l}5.3 \\
{[4.8-6.0]}\end{array}$ & 26 & $\begin{array}{l}267,441 \\
{[7,113-} \\
3,719,717]\end{array}$ & $\begin{array}{l}5.4 \\
{[3.9-6.6]}\end{array}$ \\
\hline $\begin{array}{l}\text { Culture } \\
\text { negative }\end{array}$ & 32 & $\begin{array}{l}264,650 \\
{[12,438-} \\
3,585,395]\end{array}$ & $\begin{array}{l}5.4 \\
{[4.1-6.6]}\end{array}$ & 1 & 0 & - \\
\hline
\end{tabular}

\section{Conclusion}

$>$ Substantial gonococcal bacterial DNA loads are detected in both saliva and pharynx among MSM with pharyngeal gonorrhoea. These suggest that gonorrhoea can be transmitted via sexual practices exposed to saliva such as oro-anal (rimming), and saliva use as a lubricant for anal sex. 